Dublin Institute of Technology

ARROW@DIT

Articles

National Institute for Transport and Logistics

2004-01-01

\title{
Tradition Versus Technology: Careers Fairs in the 21st Century
}

Christiane Brennan

Dublin Institute of Technology

Margaret Daly

Dublin Institute of Technology

Eileen Fitzpatrick

Dublin Institute of Technology

Edward Sweeney

Dublin Institute of Technology, edward.sweeney@dit.ie

Follow this and additional works at: http://arrow.dit.ie/nitlart

Part of the Civil and Environmental Engineering Commons, and the Education Commons

\section{Recommended Citation}

Brennan, C., Daly, M., Fitzpatrick, E., Sweeney, E.: Tradition versus technology:careers fairs in the 21st century. International Journal for Educational and Vocational Guidance, Vol. 4, No. 1, pp. 23-41. 2004.

This Article is brought to you for free and open access by the National Institute for Transport and Logistics at ARROW@DIT. It has been accepted for inclusion in Articles by an authorized administrator of ARROW@DIT. For more information, please contact

yvonne.desmond@dit.ie, arrow.admin@dit.ie.

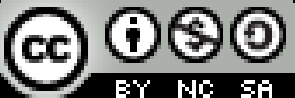




\title{
Tradition versus Technology: Careers Fairs in the $21^{\text {st }}$ Century
}

\author{
CHRISTIANE BRENNAN, MARGARET DALY*, EILEEN FITZPATRICK AND EDWARD \\ SWEENEY \\ Dublin Institute of Technology, Fitzwilliam House, 30 Upper Pembroke Street Dublin 2, Ireland ( ${ }^{*}$ Author for \\ correspondence: E-mail: margaret.daly@dit.ie)
}

\begin{abstract}
The traditional methods of graduate recruitment do not adequately meet the needs of the changing profile of students and graduates. As industry becomes internationalized, the needs of employers are also changing. Graduate recruitment is in response to short term needs and varying levels of experience are required. A case study method was used in Dublin Institute of Technology to evaluate effectiveness of a virtual careers fair in providing greater access to job opportunities for students and graduates. Access by employers to potential employees was also measured. Findings showed that while access improved, other issues requiring attention emerged.
\end{abstract}

\section{Introduction}

Up to the 1980s graduate recruitment was a predictable exercise for all parties- students, graduates, employers and career services. By the mid '80s it was obvious that more preparation was required for transition to the workplace than had been traditionally provided by careers services (Atkinson, 1985; Clutterbuck, 1985; Coldstream, 1994; Hawkins \& Winter, 1995).

Students and graduates were now forced to be more proactive and self-reliant in managing their own careers (Bridges, 1995; Duncan \& Oates, 1996). As a result, career services began to focus on the wider picture of career planning and development and increasingly this has been integrated into the curriculum as a subject in its own right (Watts \& Hawthorn, 1992; Ball \& Butcher, 1993; Huster et al., 1998).

\section{The Careers Fair}

Within the context of career planning and development, the careers fair provides students and graduates with the opportunity to research the current jobs market and to begin the transition into the workplace. The traditional careers fair in Ireland takes place over a period of 5-6 hours on one day during term, at which students and graduates visit company stands to gather information and graduate vacancies on offer. Staging a careers fair in the $21^{\text {st }}$ century that can be accessed by students and graduates and that also meets employers need is proving to be a complex challenge.

One factor contributing to this challenge is the increase in student population. The 1998 UNESCO World Conference on Higher Education reported that the 82 million enrolled in higher education represented a six-fold increase between 1960 and 1995 . A parallel rise has occurred in Ireland where currently over 115,000 students are fulltime study, compared to 19,000 in 1966 (Skilbeck, 2001). The impact of the traditional careers fair has been that students find themselves queuing at the company stands and often, due to other demands on their time, leave the fair without having spoken to all relevant employers.

Apart from the increase in student numbers there are other access issues that need to be taken into account. A total of $54 \%$ of all fulltime students in Ireland have part-time jobs and work on an average of 14 hours per week. Their earnings from term-time jobs and 
work are the most important source of their income (Ryan \& Kelly, 2002). As a result a considerable number of students find it difficult to attend events outside regular class time.

For mature students, part-time students and graduates, one can speculate that the demands on time are even greater. It can hardly be anticipated that those who are trying to fill a number of roles such as homemaker, parent, worker, and student can easily adjust their daily routine to attend extracurricular events.

The expansion of e-learning is creating further barriers to attending the traditional careers fair. Recent reports have put the size of the global market for e-learning at several billion dollars. Institutions that wish to prosper in this marketplace will be offering courses across the globe where time and boundaries will not be constraints (Price Waterhouse Cooper, 2000). It is inevitable that a proportion of both students and graduates will eventually be scattered around the world. This raises questions as to the relevance of a careers service that does not harness the e-learning to deliver its service to its clients.

Technological development is transforming the delivery of services in many areas and this has given rise to a culture where the internet is seen as providing immediate and easy access to a whole range of requirements. According to Watts and Dent (2002, p.17) "consumers want a service to be available when they identify a need for it, with minimum delay and minimum effort: they want it here, and they want it now'.

An examination of careers service websites internationally reveals the popularity of the traditional careers fair as a means for providing a link between students and graduate recruiters. The University of Melbourne (n.d.), for example, reports on its site that over 2000 students and 40 recruiters attended their Careers Fair in 2002. The University of Wollongong (n.d.) provided two Careers Fairs in 1999, as well as encouraging students to attend those of other universities. The CSU (n.d.) website reveals that most of the major universities in the UK host Careers Fairs, and some of these, such as University of Manchester and UMIST (n.d.), Huddersfield University (n.d.) and University of Liverpool (n.d.), dedicate part of their website to providing information about the fair and tips for students on how to prepare to make a positive impression with the recruiters. According to the AGCSI/GTI (n.d.) website all the universities in Ireland provide traditional careers fairs.

All of these fairs are conducted over a period of approximately five hours and involve students, all in some cases graduates, moving around exhibition stands in order to talk to recruiters about their company, the positions on offer, the potential for career progression and the recruitment process. While the websites provided a facility for feedback from users on the success of the fair, Huddersfield University (n.d.) is the only one located that published the results and feedback from the recruiters. The picture presented was a familiar one from the careers service staff. Though the event was considered enjoyable, there were comments made about the low numbers of students in attendance, their lack of knowledge about the companies' business and the small number of CVs submitted. One recruiter was reconsidering future attendance. From the student perspective the question must be asked as to whether a five-hour event attended by large numbers is the most satisfactory way of finding a first job. Access to such events for graduates also needs examination. Apart from the questions raised about the effectiveness of a traditional careers fair in the traditional higher education setting, there are also access issues that need to be resolved for those with disabilities, on distance education programmes or working abroad. 
Employers are increasingly turning to technology for the purpose of recruiting graduates. Careers services have noticed the increase in the number of employers providing online application forms and pages on their websites dedicated to graduate opportunities. An investigation by Galanaki (2002) revealed that the factors that influence companies to recruit online are, in order of priority, cost-effectiveness, high response rate, access to the passive job seeker and marketing of the company. While online recruitment was found to be more popular in large companies, its user simplicity and low cost makes it attractive option for smaller companies too.

According to Hunter (2002), due to the changing attitudes to technology and the increasing pressure or traditional methods of communicating with and attracting graduates, the recruitment market demands a flexible multimedia approach.

\section{Investigating Other Options at Dublin Institute of Technology}

In view of the present situation a key question becomes: How can a careers fair become an element of a career planning programme in a way that is appropriate for a modern Higher Education institution and a $21^{\text {st }}$ century workplace?

This was a major question at the Dublin Institute of Technology (DIT). For a long time the institution had been hosting traditional careers fairs as part of a Graduate Recruitment Programme. The annual Graduate Recruitment Programme runs from October to March and is an opportunity for employers to promote both current and future vacancies. For a number of years requests from employers to meet students and graduates were also facilitated through the provision of daytime and evening presentations oncampus. This approach proved to be less than satisfactory as attendance was often very poor.

Some of the reasons for the lack of success might have been part of the specific situation of DIT. DIT is the largest higher educational establishment in Ireland. It provides both full and part time programmes, has 21,000 students pursuing more than 400 different courses at apprenticeship, certificate, diploma, degree and postgraduate level. It also has 44,000 alumni registered throughout the world. Based on six main websites around Dublin city centre, it comprises six faculties- Applied Arts, Built Environment, Business, Engineering, Science and Tourism and Food. In some instances the faculty is also split between sites, for example, in the case of engineering. Industry and professional bodies provide an input into course design and the percentage of DIT's graduates entering directly into employment on completion of their course is consistently higher than the national average (DIT, 1998, 1999, 2000).

In addition, the specific situation of the careers service, established in 1992, might have influenced the situation. One of the challenges for the careers service is that it is situated off-campus at DIT's Administrative Centre, over one kilometer from its nearest student site.

In March 1999, in an attempt to better facilitate employers, students and graduates, faculty based traditional careers fairs were introduced. An evaluation of these revealed that though an improvement, some difficulties still existed for each of the stakeholders.

Students. Feedback from the students indicated that the amount of time required to attend a careers fair meant they would have to miss lectures or take time out of their final year 
project work. This is the matter of concern for them. They also reported that due to the demands of part time work they could not stay on-campus once classes ended. In addition, preparation of CVs took time that they could not afford while studying for final year examinations. For students participating in distance learning or part time evening courses, attendance at a fair was often impossible.

Graduates. Few graduates could take time off work to attend a traditional careers fair. Others would have long distances to travel if they lived outside Dublin. As there is a trend amongst alumni to migrate, those hoping to return home for employment reported difficulties accessing information on graduate opportunities.

Employers. The careers service found it impossible to select a date for a careers fair that was suitable for all interested employers and, as increasingly employers are recruiting all year round, they may not know their recruitment needs at the time of a careers fair. Graduate employers often commented on the expense incurred in taking some of their technical/professional staff offsite for careers fairs and this was a particular concern where the numbers of students and graduates attending were lower than anticipated. At more popular information stands students and graduates had to queue to speak to employers, and often left without doing so due to frustration or to attend a scheduled lecture. Employers were also concerned about the time lapse between student/graduate attendance at a fair and the receipt of CVs or completed application forms at the company. They were often disappointed at the number eventually received.

Careers Service. There was concern about the amount of time and budget spent organizing an event that lasted only a few hours and where it was not possible to provide equality of opportunity for all students and graduates. The split structure of DIT caused logistical problems in transporting students to the venue and it was becoming impossible to provide a venue large enough for the number of companies wishing to attend.

Dublin Institute of Technology. The employability of its graduates plays an important role in attracting and retaining students within DIT. The Institute values its profile with alumni and wishes to enhance its services to them. There has been a long history within DIT of links with industry and facilitating access to its graduates is seen as an important part of this relationship. The traditional careers fair was not meeting to the standards required by DIT in this regard.

\section{The Virtual Careers Fair}

Having tried a number of different approaches in the past was found that they did not deal satisfactorily with issues of access for students or graduates. Difficulties experienced by employers and careers service staff remained the same, and in some cases grew.

It was decided that a radical and innovative approach was required in order to respond to the needs of major stakeholders. After an initial investigation of other possibilities it was decided to employ a technological approach. It was hypothesized that benefits could be enhanced through a virtual careers fair that would provide access to 
employers on-line, and a CV Bulletin Board where employers could search for suitable candidates. The specific objectives were:

- To provide greater access to employment opportunities for final year students and graduates;

- To provide employers with a fast, efficient, flexible means for promoting their graduate vacancies to a wider audience;

- To deliver this element of the career planning programme in a way that made better use of careers service time;

- To enable DIT to provide a better service for alumni and to strengthen and enhance its links with industry.

In May 2001 as a result of discussions with members of DIT's senior management team, a strategic decision was made that the careers service would host the first ever virtual careers fair in higher education in Ireland. Comprising of three facilities, it would include:

- A careers fair element where employers could advertise current and forthcoming graduate vacancies, and accept applications online, by email and via letter post, from DIT students and graduates;

- Two CV Bulletin Boards- one each for students and graduates- containing CV template to be completed online. This would be used to apply directly for vacancies advertised on the site, and could be updated as desired by each user;

- Employer CV search facility to be made available to registered recruiters enabling them to search for relevant CVs by discipline or key word.

It was obvious from the beginning that creating a virtual careers fair would be a major project with far-reaching implications. It was decided to adapt an approach that would allow planning, action, observation and reflection in a cyclical fashion. An action research approach was considered the most appropriate methodology as the research design could be redefined as the project progressed. To increase the likelihood of success it was considered imperative to involve the major stakeholders in the project throughout the design, implementation and evaluation stages. Taking such an approach would enable the careers service to improve its practice, its understandings and the situation in which it works (Carr \& Kemmis, 1986). The action research would also provide a means through which stakeholders could be involved in the process and through which both qualitative and quantitative data could be interpreted.

\section{Planning}

A project team, comprising the Employer Liaison Officer, the Head of Careers Service and one Careers Adviser, was formed and a project management plan devised. The plan was divided into a number of phases that would be implemented over a period of five years. Phase 1, the pilot phase, would focus on students and recent graduates from the faculties of Engineering and Science (including IT). The website would be launched on $31^{\text {st }}$ October 2001 and would remain live for the duration of the Graduate Recruitment Programme.

The next step was to discuss the concept with the key academic staff from the relevant faculties and enlist their support. They expressed enthusiasm for the project and, following their recommendations, the search began for a company that would design the site of the project team's specification (see Figure 1) and within the time 
frame July to October. New Media Design Ltd (Dublin), in partnership with BSM Ireland Ltd (Galway), were engaged to provide and maintain both the front and back end workings of the site.

\section{Implementation}

Branding. To ensure that the name and image were attractive to students and graduates, a competition was run throughout DIT and a sponsored prize offered for the best name. A judging panel was formed from DIT staff under the age of 25 , some of whom were part-time students or recent graduates, and choiceatdit.ie was agreed name for the site. The design company created a logo and the domain name was registered. Specialised legal advice was sought in relation to the design copyright of the site, and copyright assignment documentation was drawn up for all parties.

Marketing. Separate marketing campaigns were devised for all stakeholders. Feedback was obtained from students regarding the design of flyers and posters that would grab their attention and arouse curiosity. As a result of the campaign the name chioceatditie was readily adopted by the student body. Flyers were developed to provide relevant information for graduates. These flyers were enclosed with mailshot regarding their forthcoming graduation ceremony and also with the normal graduate recruitment literature notifying relevant employers of the introduction of the virtual careers fair. Emails were sent to academic staff and also to students and employers and a notice was placed on careers service website. Class visits to relevant students were made by Careers Advisers where information was distributed, including hard copies of the CV template for the CV Bulletins Board. A Gold Card with space to write passwords and usernames was issued to final year students.

Technology. The Employer Liaison Officer was designated to liase with the two design companies. The aim was to create an employment opportunities facility were participants could access company websites, view details of graduate vacancies and apply on-line for positions of interest to them. Two CV Bulletin Boards, one each for students and graduates, and a unique CV template were required to enable employers to search these databases by specific fields. An early encountered was that DIT's web server was incompatible with the technical language required to create the site. As a result a separate hosting site was sourced.

Launch. Initially a major launch with media coverage was planned. However due to the tight deadline it was decided to postpone this until Phase 2. In order to generate publicity amongst students and staff on the launch date it was considered necessary for the careers service to have a visible presence on-campus as in previous years at a traditional careers fair. As a commitment to a longer term project DIT provided the facilities and the technology to enable the careers service to do this. In a hall set up with networked PCs, Careers Advisors were on-hand for two days to provide advice and deal with queries. Due to the support of academic staff, IT technical staff were also available. 


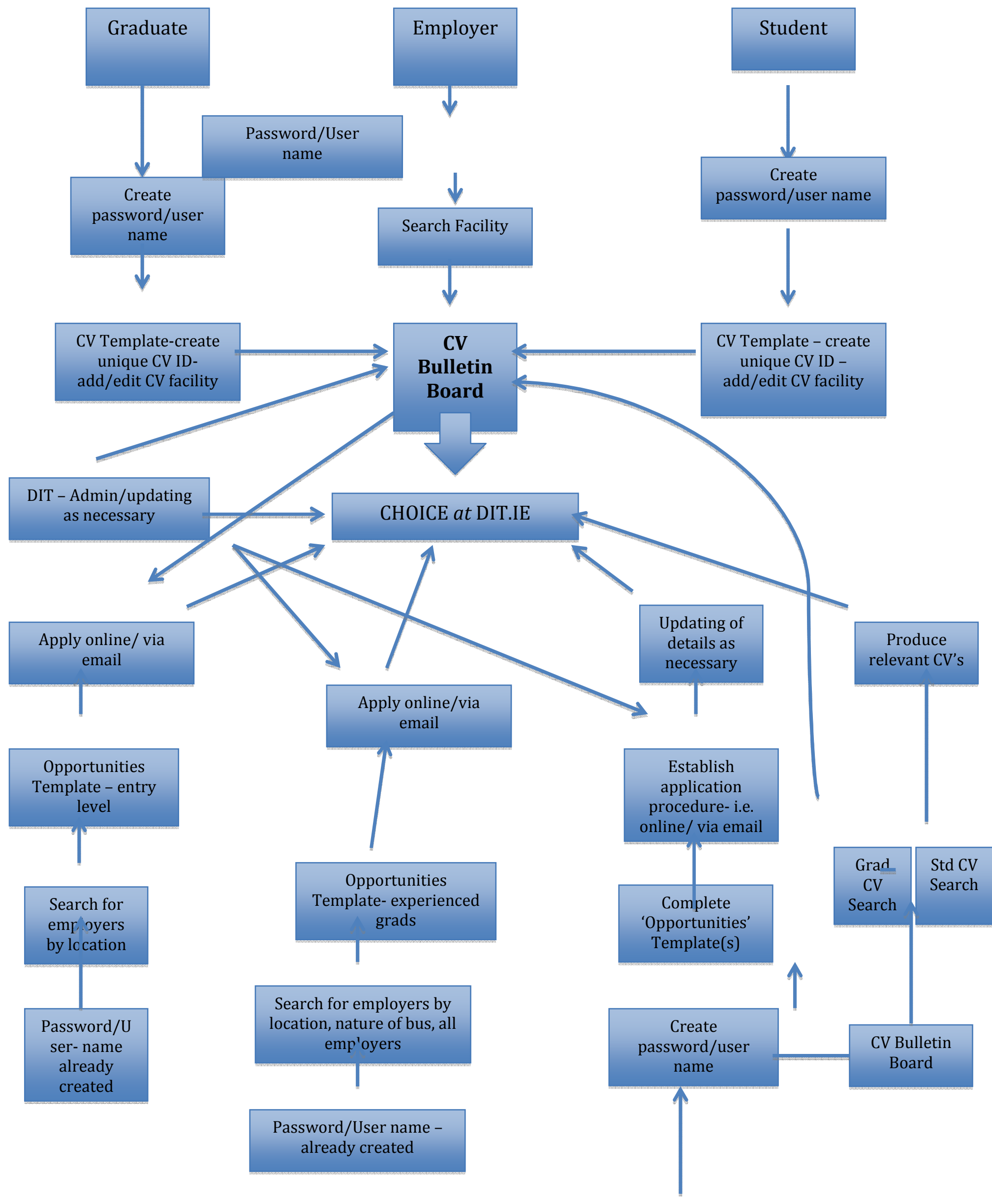



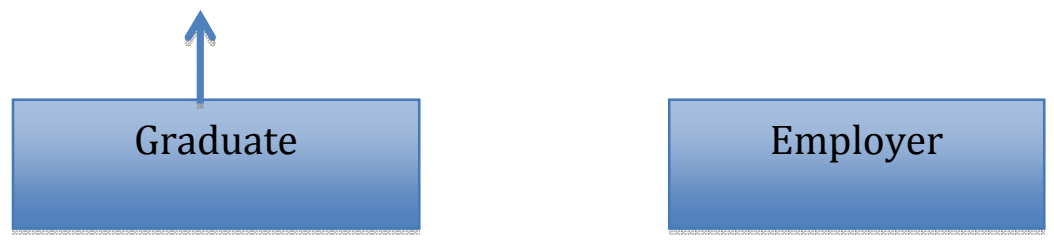

Figure 1. Specifications for virtual career fair.

Funding. The set-up costs were more than had been initially envisaged and the financial support provided by DIT was essential to the completion of Phase 1 . While further development and regular maintenance will be required it is envisaged that through employer participation charges, choiceatdit.ie will become completely self funding over the 5 year project plan.

\section{Evaluation}

Using action research a number of methods were adopted to establish a comparison of access between the traditional and virtual careers fairs. These included gathering statistical data, recording anecdotal information, carrying out survey and semistructured interviews. The comparisons drawn were taken from the viewpoint of the stakeholders i.e. students, graduates, employers, DIT and the careers service.

Anecdotal information was gathered through feedback from students and graduates. This information was sought through informal interviews, electronically via email, and a feedback button was provided on main pages of the site. Responses were gathered from 38 students and 15 graduates. In addition to this a formal evaluation with students and graduates was done by a survey sent by email to all who had registered on the website. They were asked to answer the following question:

In your opinion, what do you think are the advantages and/or disadvantages of having the careers fair online as opposed to a traditional careers fair (NB: A traditional careers fair means companies putting up information stands in the college for a few hours one day.

In relation to the institute and the careers service the anecdotal information was the principal form of feedback. Information from the institute was gathered by receiving feedback form six members of staff in DIT during conversations and via email, as well as one semi-structured interview. The respondents included two academic staff, two administrative staff, one class tutor and IT technician. The semi-structured interview within the institute was carried out with a faculty administrator in DIT. This person has a first-hand experience of both types of fair as he has responsibility for to co-ordination of all events held on-campus. He asked the following questions: 
- In what way do you think the careers fairs changed by it being a virtual fair?

- What are the advantages and/or disadvantages of the traditional careers fairs?

- What are the advantages and/or disadvantages of the virtual careers fair?

- Does this change affect our service alumni?

- Does this change affect the service we offer to employers?

A semi-structured interview was used to gather employer feedback. The semistructured interview was carried out with the recruitment officer of a major multinational company that had taken part in previous traditional careers fairs and also registered to participate in the virtual careers fair. The interview with the employer was structured around three questions:

- In your opinion what are the advantages and/or disadvantages of the traditional careers fair?

- In your opinion what are the advantages and/or disadvantages of the virtual careers fair?

- In what way has the services we offer employers changed?

\section{Results}

\section{Students}

The number of students participating in the virtual careers fair increased considerably $(+66 \%)$. While only 324 students registered for the 2000 edition of the traditional careers fair, 538 registered with the choiceatdit.ie in 2002.

From anecdotal information it became clear that the students saw some benefits, but also some disadvantages, to the virtual fair. Among these they mentioned:

Time. With the heavy workload in their final year and the numbers in part-time employment, students commented on the fact that virtual careers fair resulted in a "very effective use of time". By inputting their CV once, it was then accessible for any number of companies to view.

Accessibility. Students commented on the advantage of being able to access the virtual careers fair twenty-four hours a day from anywhere and that they could "revisit it when it suited" their availability. They liked the fact that the fair was ongoing and remarked that with a traditional fair, if they could not attend that day, they missed the whole event.

Technology. Students were very enthusiastic that the virtual careers fair used technology, but found technical problems with the website very frustrating especially when they lost information they had inputted.

Employer contact. Students remarked that a drawback of the virtual careers fair was that they "missed the opportunity to talk directly to representatives from companies".

Accessing Employment Opportunities. Students felt that since their CV is available for employers to access from October to April, it has the potential to be viewed by greater 
numbers of employers who take part in the virtual careers fair over this period, as opposed to the once off traditional careers fair. However some also commented on the disappointingly small number of employers that took part in the virtual careers fair.

The survey with the students was less successful. In spite of having used email to distribute this survey question, disappointingly, no responses were received. By using only one open-ended question we had limited our chances of receiving responses. Likewise, students did not make much use of the feedback facility that is built into the site. Current research aimed ongoing evaluation of the website is addressing this issue.

\section{Graduates}

The increase of graduates participating in the fair was beyond expectations. The number of registered increased from eight in 2000 Fair to 562 who had visited choiceatdit.ie.

The anecdotal information indicated that the graduates saw advantages but also come inconveniences.

Time. Comments were made on the effective use of time with the virtual careers fair. Having input a CV only once and being able to update this at a suitable time was seen as advantageous. However technical problems resulted in the loss of data entered y users in the early stages.

Accessibility. Graduates were very pleased to see the fair being organized in such a way that they could participate without being physically present. They commented that "attending a traditional fair is an impossibility".

Inconclusion. Graduates were very pleased to see the creation of a new idea that provides them with "an opportunity to be included in this recruitment programme".

Employment Opportunities. It was remarked that it is beneficial to be able to easily see which employers are taking part and their opportunities available on an ongoing basis.

Technology. Graduates were pleased to see the shift to the use of technology, but however commented that the site is dependent on effective technology. The difficulties it presents when problems arise are "off-putting and time consuming".

The survey with the graduates was also less successful. There was on response received. The graduate wrote:

I have found the site very useful due to the information, contacts, and sites provided. The site is more beneficial for students who have graduated and are unable to attend career fairs in college. I feel that the companies however often leave up positions which have already been filled and don't inform your service. I have applied for a number of jobs where I didn't even get a response, eventually my ringing them they informed me that positions have been filled for months now! 
Again, by using only one open-ended question we had limited our chances of receiving responses. As with students, graduates did use feedback button incorporated into the system. Current research aimed at the ongoing evaluation of the website is also addressing these issues.

\section{Employers}

The number of employers showed an increase from 17 in 200 to 28 for the virtual careers fair. Of those who registered, seven employers had placed their opportunities on the site by the launch date. This small number was due to the sharp global downturn in these particular sectors around the date of the launch. However by March 2002, fifteen companies had placed vacancies on the site.

The employer that was interviewed also had mixed feelings about a virtual careers fair. The responses can be summarized as follows:

Contact with students. With a traditional careers fair it is possible to talk to students, have personal contact with them and "give them a feel for what it would be like working for a company".

Time. Traditional careers fairs require too much traveling around the country and even more "all careers fairs tend to happen around the same time which cause logistical difficulties".

Accessibility. The virtual careers fair is accessible to everyone for a longer period than a traditional careers fair and distance is not an obstacle. Those who can't attend a traditional fair can be kept up to date with job opportunities through the virtual careers fair. Importantly "the virtual fair has the additional advantage that you can attend the fair and get CVs from your desk".

Accessing Curriculum Vitae. The virtual careers fair has the advantage that "you can get CVs at any stage", however in some cases not enough information is filled in. This is particular company had a sudden requirement for graduates to fill positions quickly, and through the search facility on the CV Bulletin Board, got thirty relevant CVs instantaneously.

The employer's final comment was that "choiceatdit.ie gives instant results with less hassle" and the wish was expressed that "all universities did the same".

\section{Institute}

The reaction of the DIT staff-members to the virtual careers fair was positive.

Use of technology. They commented that they were impressed by how this change to virtual careers fair had harnessed the use of technology, and that "as technological institution, were very pleased to see this change". 
Industrial contact. It was remarked that DIT is "keen to see students interacting with employers" and that DIT is seen as being proactive in its contact with industry.

Initiative. There was general agreement from them that the idea is "an excellent initiative and is one we will be recommending to our students".

The semi-structured interview with the faculty administrator yielded similar results. His response can be summarized as follows:

Improved service to alumni. He expressed satisfaction that the virtual careers fair enabled DIT to provide an efficient means for alumni to participate.

Use of technology. He commented that it was excellent to see the institute actively using technology in the employment programme.

Innovation. He viewed it as positive that DIT is the first in the higher education sector in Ireland to take the virtual route and are thus creating an "appearance of leading edge" in this field.

Links with industry. Being a permanent fixture over a six month period, he remarked that it results in improved contact with employers, and provides a simple and efficient method of graduate recruitment.

His final comments were while he could see the benefits of a traditional careers fair, he thought it was "good to move with times" and use available technology. He saw the move to the virtual careers fair as a "vast improvement" and said he "wouldn't be keen to see a reversion back to the traditional fair".

Careers service.

The impressions and opinions of the project team on the comparison between organizing a traditional and a virtual careers fair were mixed.

Time. Although much time was devoted to this pilot project, it was agreed that in subsequent years the amount of time necessary for further development of choiceatdit.ie will be less than that usually devoted to organizing a traditional fair. As the project team consisted of just three people, and the provision of a virtual careers fair was but a small part of the work of the careers service, it was a major undertaking to have the project live in under four months with no compromise to the level of service provided to students, graduates, employers and academic staff.

Technology. Owing to increased use of technology by employers in graduate recruitment, the careers service is keen to provide this element of the career planning programme in line with these advances. By hosting a virtual careers fair the aim is to provide an efficient and effective method of recruitment to students, graduates and employers. The main 
drawbacks to using technology are that the local system must work perfectly in order for it to be effective, and that even after exhaustive testing, technical hitches can still occur.

Profile. The profile of the careers service is enhanced by providing an alternative option to a one a day event that increases accessibility for all users.

Improved service to employers. Choiceatdit.ie provides an easy time efficient means of recruitment for employers and enables companies to advertise their opportunities to students and graduates as they arise over a six month period. In the past employers have had difficulties in raising awareness of their company is included in the active promotion of this service, as carried out by the careers service.

Students and Graduates. Having made the transition to a virtual careers fair, it has been demonstrated that it is more accessible to students and graduates. They are no longer restricted to attend one-day basis. In addition, the provision of a facility for students and graduates to post their CV on-line has proved to be very popular and time saving.

Institute. Making the transition to a virtual careers fair is very much in line with the ethos of DIT. The survey of First Destination Award Recipients statistics for 1998, 1999 and 2000 (DIT, 1998, 1999, 2000) indicate the success noted that in spite of the severe economic downturn, this did not adversely affect graduate employment. The virtual careers fair provides a flexible option for building relationships with employers in an unstable economic climate.

\section{Conclusions}

One of the main objectives in introducing a virtual careers fair was to increase accessibility to employment opportunities for students and graduates. Preliminary research has demonstrated that this objective has been achieved. However, technical difficulties were eventually overcome, many students and graduates lost data that they had inputted into the CV Bulletin Boards and were confronted with the task of having to repeat the exercise.

The project was most successful in improving the service to employers. It allowed them to present their graduate opportunities and to receive applications, all without leaving their desk. However employers must be actively encouraged to keep their job opportunities information current.

The careers service spent considerably more time organizing the virtual careers fair than would be spent organizing a traditional careers fair. However the time required for the continuation of the project is expected to decrease incrementally as each phase is completed. The careers service also needs to consider what means can be provided for face-to-face interaction between employers and potential employers and for receiving feedback from users of choiceatdit.ie.

\section{Recommendations}

It is important when planning a virtual careers fair to keep the project small and as simple as possible and to develop it on a step-by-step basis. The Project Team discovered that this 
project needed considerably more planning time than was available and insufficient time was built in for testing. A valuable lesson learned was that testing requires at least three times the amount of time envisaged. Budgeting is a vital component and must include provision for contingencies and hidden costs.

When dealing with a design company it is important to remember that what is obvious to the careers service in terms of requirements is not necessarily obvious to anybody else. A good open relationship with the design team can help overcome many communication difficulties.

The Project Team needs to support of in-house technical expertise in drawing up the specification and monitoring the technical aspects of the project. Above all, support from senior management of the institution is essential to the success of such innovation project and a sense of humour and good relationship within the Project Team help overcome many a set-back.

For the careers service, having completed phase 1 of choiceatdit.ie, even more challenging is the realization that technology itself, is not in itself, the source of improvement from a student, graduate, employer, or institute point of view. The improvement derives from developing robust graduate recruitment strategies and then implementing them superbly.

\section{References}

Association of Graduate Careers Services in Ireland/GTI Ireland (AGCI/GTI) (n.d.). Student events. Retrieved Nov. 25, 2002, from http://www.gradireland.com/events/events.asp?bhcp=1.

Atkinson, J. (1985). The changing corporation. In D. Clutterbuck (Ed.), New patterns of work. Aldershot: Gower Publishing Company Ltd.

Bridges, W. (1996). Jobshift. London: Nicholas Brealey Publishing Ltd.

Ball, B., \& Butcher, V. (1994). Developing students' career planning skills. London: Department of Employment.

Carr, W., \& Kemmis, S. (1986). Becoming critical. London: The Falmer Press.

Central Services Unit (CSU) (n.d.). Careers fairs. Retrieved Dec. 2, 2002. From http://www.prospects.ac.uk/cm s/ShowPage/Home_page/Fairs/p!egakl?mode=show_prospects_bycat\&id=1.

Clutterbuck, D. (1985). The brave new world of work. In D. Clutterbuck (Ed.), New patterns of work. Aldershot: Gower Publishing Company.

Coldstream, P. (1994). Training minds for tomorrow: A shared responsibility. Higher Education Quarterly, 48, 159-168

Dublin Institute of Technology (DIT) (1998). First destination of award recipients survey. Unpublished manuscript. Dublin Institute of Technology, Ireland.

Dublin Institute of Technology (DIT) (1999). First destination of award recipients survey. Unpublished manuscript. Dublin Institute of Technology, Ireland.

Dublin Institute of Technology (DIT) (2000). First destination of award recipients survey. Unpublished manuscript. Dublin Institute of Technology, Ireland. 
Durcan, J., \& Oates, D. (1996). Career paths for the 21st century. London: Random House.

Galnaki, E. (2002). The decision to recruit online: A descriptive study. Career Development International, 7(4), 243-251.

Hawkins, P., \& Winter, J. (1995). Skills for graduates for the 21 $1^{\text {st }}$ century. Cambridge: Association of Graduate Recruiters.

Huddersfield Univeristy Careers Service (n.d.). Careers fairs. Retrieved Nov. 22, 2002, from Huddersfield University Careers Service, webpages: http//www.hud.ac.uk/careers/fair_prep.php.

Hunter, M. (2002). Address on behalf of Monster,com at the annual meeting of TCS Centre Managers. Birmingham: Aston University.

Huster, D., Ball, B., Carter, K., Halsall, R., Ward, R., \& Watts, A.G. (1998). Developing career management skills in higher education. Cambridge: CRAC.

Price Waterhouse Coopers (2000). Business model for the euniversity. London: Higher Education Funding Council for England.

Ryan, L., \& O'Kelly, C. (2002). European students survey 2000: Ireland report- social and living conditions of higher education students. Dublin: Higher Education Authority.

Skilbeck, M. (2001). The University challenged: A review of international trends and issues with particular reference to Ireland. Dublin: Higher Education Authority.

University of Liverpool Careers Service (n.d.) Recruitment fairs. Retrieved Dec. 3, from University of Liverpool Careers Service in 2002, webpage:

http//www.liv.ac.uk/ccap/careers_service/fairs/fm2002/attend_student.htm.

University of Manchester and UMIST Careers Service Careers Service (n.d.). Careers fairs programme. Retrieved Dec. 2, 2002, from University of Manchester and UMIST Careers Service, webpage: http//w ww.graduatecareersonline.com/events/detail.asp?EventID=242.

University of Melbourne Careers Service (n.d.). Careers fairs. Retrieved Dec. 2, 2002, from University of Melbourne Careers Service, webpage: http://www.services.unimelb.edu.au/careers/students/grad_jobs /gep/fairs_info.htm.

University of Wollongong Careers Service (n.d.). Careers fairs. Retrieved Dec. 2, 2002, from University of Wollongong Careers Service, webpage: http://www.uow.edu.au/student/careers/services/fairs.html.

Watts, A.G., \& Dent, G. (2002). Let your fingers do the walking: The use of telephone helplines in career information and guidance. British Journal of Guidance and Counselling, 30(1), 17-35.

Watts, A\&G., \& Hawthorn, R. (1992). Careers education and the curriculum in higher education. Cambridge: CRAC. 